\title{
EVALUATION OF EDUCATION IMPLEMENTATION OF TRAINING PIM III IN AGENCY OF HUMAN RESOURCE DEVELOPMENT
}

\author{
Kencana Sari*, Mukhneri Mukhtar**, Yetti Supriati*** \\ State University of jakarta \\ State University of jakarta \\ State University of jakarta \\ kencanasari00@gmail.com \\ mukhnerimukhtar@unj.ac.id \\ yettisupriati@unj.ac.id
}

\begin{abstract}
This study is a qualitative research aims to find out how the implementation of leadership level III training at Human Resources Development Board of Province of South Sumatera based on: (1) participant's satisfaction covers: participant's satisfaction to widyaiswara or resource person, participant's satisfaction to organizer committee service, participant's satisfaction on training materials, participant's satisfaction on training schedule, Participants on training facilities and infrastructure, and participant's satisfaction with the training consumption; (2) learning activities include: participant activity in learning process, widyaiswara activity or resource in learning process, and organizer activity of organizer in learning process; (3) changes in the behavior of alumni after returning to their respective duties, including: behavioral changes in implementing management functions, behavior change in task delegation, behavior change in coordination, and behavior change in decision making; (4) Impact of change in employment behavior of alumni to improve agency performance; and (5) Impact of change in work behavior of alumni to improve service quality of institution.
\end{abstract}

Keywords: Evaluation, Educational, Training and Leaderships.

The problem of leadership competence is the main factor in realizing the excellent service to the public through the performance of the government given by the ranks of the government apparatus. Leadership capabilities and competencies will be seen in the leadership qualities of the officers who lead the service operational work units at the echelon of responsible positions in government organizations, both at the central government level and at the local government level.

Based on the assessment of the fulfillment of service standard components in 33 provincial governments, conducted by the Ombudsman of the Republic of Indonesia in 2016, shows that the level of public service in the provincial government of South Sumatra is included in the green zone and is ranked 12th from 33 provinces in Indonesia with 82.59 points viewed from the high level of compliance with the fulfillment of public service standard components.

However, it is contradictory to the results of preliminary observations made by researchers to several agencies within the provincial government of South Sumatra, where it was found that the quality of public services received by the community was poor, complaints, long service time, no Minimum Service Standards (SPM) and still the practice of illegal levies (pungli) in some public service units in South Sumatra Province. For example, government-run services in Building Permit Permit (IMB) units, Business Licenses, Motor Vehicle Testing Services, Hospital Services, Sub-district Offices, Sub-districts and other public service offices are still considered low-quality and not in line with what is expected by community as a public service connoisseur.

Recognizing the low level of public services, the provincial government of South Sumatra through the South Sumatra Provincial Training and Training Agency continuously and planned to improve the quality of Human Resources (HR) or the State Civil Apparatus (ASN) within the scope of the provincial government of South Sumatra through increased leadership competence of officials and the performance of government agencies through education and training programs (Training) leadership that is expected to 
produce ASN human resources who have managerial competence, insight and a broad vision and professionals in the field.

One effort that has been done BPSDMD South Sumatra Province in forming leadership is through the Level III Training Program Leadership. Based on Leadership Training Handbook Level III of South Sumatra Province Year 2017 states that the purpose of implementation of Leadership Level III Training is to increase the leadership competence of echelon III structural officials who will play and perform the duties and functions of governance in instansinya each.

Based on the above description, the researcher is interested to conduct an evaluation research about: "Evaluation of Leadership Education and Leadership Training Level III in Human Resource Development and Regional Development of South Sumatera Province"

\section{METHOD}

The research approach used in this research is a qualitative approach. Meanwhile, the design of the evaluation research using the Kirkpatrick evaluation design introduces the "The four levels" model: reaction level, learning level, behavioral level, and the product level.

In evaluating reaction level, the researchers measure: (1) The participant's response to the ability of the speaker / resource person in mastering the taught meta, conveying the material with clear sentence pronunciation, responding to the participants' questions well, lifting examples of cases appropriate to the task and the function of the participants, carrying out the tasks with full discipline, and manage the class well; (2) The participants' responses to the organizing committee, including: hospitality of the organizing committee in serving the training participants, the ability of the organizing committee in performing the task well, and the performance of the organizing committee in serving the training participants; (3) Participants' responses to the training materials, including: presentation of training materials, relevance of the content of the training materials to the tasks and functions of the participants, the assigned tasks / exercises, the teaching modules / teaching materials used, and the learning media used; (4) Participants' responses to the training schedule, including: setting the schedule, the adequacy of the rest period for each session of the activity, and the allocation of the wakti provided; (5) Participants' responses to training facilities and infrastructure, including: accommodation facilities, completeness of learning facilities, health facilities, sports facilities / recreation; and (6) The participants' responses to the consumption of the training, covering: consumption menu, consumption presentation, snack provision, consumption adequacy.

In the evaluation of the learning level, the researchers measure the skills, attitudes and behaviors of participants during their education and training. In evaluating behavioral levels, measuring behavior change of participants / alumni after attending education and training and returning to their respective duties, including aspects of ability in terms of: (1) Implementing management functions; (2) Delegation of assignments ,; (3) Coordinate; and (4) decision making. While on the evaluation of product level, the researcher measured the effect of the change of work behavior of alumni on the improvement of the performance and the quality of service of the institution.

\section{RESULTS AND DISCUSSION}

Based on the analysis of research data, it is found that (1) Participants give good reactions to the implementation of education and leadership training level III implemented by the Regional Human Resources Development Board of South Sumatra Province in 2017. This is supported by several facts, positive response to the widyaiswara / resource persons, organizing committee, training materials, training schedule, training facilities and infrastructure and training consumption; (2) Learning conducted by participants in the implementation of education and leadership training level III implemented by the Regional Human Resources Development Board of South Sumatra Province in 2017 took place well. This is supported by several facts, where participants have satisfactory knowledge, skills, attitudes and behaviors during the learning process. In addition, the implementation of education and leadership training level III implemented by the Regional Human Resource Development Agency of South Sumatra Province in 2017 is 
running effectively, efficiently, structured and in accordance with the applicable curriculum; (3) Behavior of participants experiencing positive changes after following the implementation of education and leadership training level III implemented by the Regional Human Resources Development Board of South Sumatra Province in the Year 2017 and returned to their respective workplace. This is evidenced by several facts, where participants / alumni experience positive behavior change in terms of: carrying out management functions, delegating tasks, coordinating, and making decisions; and (4) The result of education and leadership training level III conducted by the Regional Human Resources Development Board of South Sumatera Province in the year 2017 has a very significant impact on changes in work behavior of alumni education and training in improving the performance and quality of service instansinya.

In addition, the implementation of education and leadership training conducted by the Regional Human Resource Development Agency of South Sumatra Province in 2017 is running in accordance with the plan, directed and guided by Law No. 5 of 2014 on State Civil Apparatus and Perka LAN Number 19 Year 2015, on Guidelines for Implementing Leadership Training Level III, which regulates how to achieve the competencies of the participants Training as one component of the success of the Training program.

From the above conclusion, the researcher needs to recommend some things related to the finding of deficiencies and weaknesses in the implementation of Leadership Level III Training conducted by Regional Human Resources Development Board of South Sumatera Province in the year 2017, among others: (1) The need for improvement and improvement of the quality of comfort, such as dormitories or messs provided by the organizing committee; (2) As soon as possible to overcome the problem of water shortage caused by electrical disruption by coordinating directly with related parties, in this case PT. The nearest PLN (Persero); (3) The necessity of improving the quality of service of consumption by the organizing committee, one with the appeal and attractive appearance of the servants; (3) The need for revision of the preparation of training schedule in accordance with the curriculum and renewal of renewal so that the barriers in the mastery of material received by the participants can be solved systematically; (4) The need for promptness, effectiveness and efficiency of the organizing committee capability in conducting mentoring during the learning process and sustainability of the training; and (5) The need to optimize the use of instructional media which is done either by widyaiswara or organizing committee.

In addition to the above, the implementation of education and coaching leadership level III implemented by the Regional Human Resource Development Agency of South Sumatra Province in 2017 is also necessary to improve and refine the components in every aspect that is still inadequate availability and the need for study a more focused evaluation of the learning process of education and training in order to obtain the outcomes of participants of education and training who really have the skills, skills in accordance with the goals and objectives set out in the education and training concerned.

\section{REFERENCES}

Anggraini, Renita. (2002). Evaluasi Efektivitas Pelaksanaan Pelatihan Diklat PIM Tingkat III dengan Pendekatan Kirkpatrick pada Departemen Perindustrian dan Perdagangan di Jakarta. Universitas Indonesia Jakarta.

Arikunto, Suharsimi dan Syafruddin, Cepi Abdul Jabar. (2004). Evaluasi Program Pendidikan. Jakarta: PT Bumi Aksara.

Arikunto, Suharsimi dan Syafruddin, Cepi Abdul Jabar. (2009). Evaluasi Program Pendidikan : Pedoman Teoritis Praktis Bagi Mahasiswa dan Praktisi Pendidikan, cetakan ketiga. Jakarta : Bumi Aksara.

Arikunto, Suharsimi dan Safruddin, Cepi Abdul Jabar. (2010). Evaluasi Program Pendidikan : Pedoman Teoretis Praktis bagi Mahasiswa dan Praktisi Pendidikan. Jakarta: Bumi Aksara.

Arikunto, Suharsimi. (2007). Manajemen Penelitian. Jakarta: PT Rineka Cipta.

Artikel dalam http://shareit4us.blogspot.com/2010/06/model-evaluasi-program.html. diakses pada tanggal 1 Maret 2017.

Auerbach F. Carl and Silverstein B. Luise. (2003). Qualitative Data: an Introduction to Coding and Analysis. New York: New York University Press.

Barnes, G. James. (2003). Rahasia Hubungan Pelanggan, Terjemahan Andreas Winardi. Yogyakarta: Andi. 
Bernardin and Russel. (1998). Human Resource Management, Second Edition. Singapore: McGraw-Hill Book Co.

Bernardin H. John dan Russel E. A. Joyce. (1983). Human Resources Management: An Experimental Approach. California: Mc. Graw-Hill Co.

Blaine, Worten B., James R. Sanders, dan Jodi L. Fitzpatrick. (2004). Program Evaluation Alternatives Approach and Practical Guidelines. Boston: Pearson Education Inc.

Blancard, P. Nick dan James W. Thacker. (2007). Effective Training: Systems, Strategies, and Practices. New Jersey: Pearson Prentice Hall.

Childers, Thomas. (1988). Do library systems make a difference? (Library and Information Science Research, ZO, October-December)

David, Royse, et.al. (2006). Program Evaluation an Introduction. Belmont: Thomson Brooks/Cole.

Davis, Eddie. (2005). Buku Wajib para Manager Bagaimana Menyelenggarakan Training, Terjemahan Ramelan. Jakarta: PT. Buana Ilmu Populer.

DeCemzo and Robin. (1999). Human resource Management, Sixth Edition. New York: jJohn Wiley \& Sons, Inc.

Denzin, N.K dan Lincoln, Y.S. (2009). Handbook of Qualitative Research. Pustaka Belajar: Yogyakarta.

Dessinger J. Conway dan James L. Moseley. (2004). Confirmative Evaluation: Practical Strategy for Valuing Continuous Improvement. San Fransisco: Wiley.

Djaali dan Puji Mulyono. (2000). Pengukuran dalam BIdang Pendidikan. Jakarta: PPs UNJ. Edison. 2009. Penelitian dan Evaluasi Dalam Bidang Pendidikan:Evaluasi CIPP, (Online), (http://ed150n5.blogspot.com/2009/04/evaluasi-cipp.html, 11 April 2011)

Fraenkel R. Jack, Wallen E. Norman \& Hyun H. Helen. (2012). How to Design and Evaluate Research in Education. New York: Mc. Graw-Hill.

Fuad, Noor dan Gofur, Ahmad. (2009). Integrated Human Resources Development. Jakarta: Raja Grasindo.

Gomes, et.al. (2001). Managing Human resources, International Edition. New Jersey: Prentice Hall, Inc.

Gronlund, Noman E. dan Robert L. Linn. (2000). Measurement and Evaluation in Teaching. New York: McMilan Publishing Co.

Hamalik, Oemar. (1999). Kurikulum dan Pembelajaran. Jakarta: Bumi Aksara.

Hamalik, Oemar. (2008). Kurikulum dalam Pembelajaran. Jakarta: Bumi Aksara.

Handoko, Hani T. (2001). Manajemen Personalia dan Sumber Daya Manusia. Yogyakarta : BPFEYogyakarta.

Hanggraeni, Perilaku Organisasi. (2011). Jakarta: Lembaga PEnerbit Fakultas Ekonomi Universitas Indonesia.

Hasan, Hamid. (2009). Evaluasi Kurikulum, Cetakan Kedua. Bandung: Remaja Rosdakarya.

Issac Stephen dan William B. Michael. (1983). Handbook in Research and Evaluation. California, San Diego.

Jaramis, Martini. (2010). Orientasi Baru dalam psikologi Pendidikan. Jakarta: Yayasan Penamas Murni.

Kamil, Mustofa. (2007). Model Pendidikan dan Pelatihan (Konsep dan Aplikasi). Bandung: Alfabeta.

Kirkpatrick, Donald L. (1998). Evaluating Training Programs: The Four Levels, 2ed, San Francisco: BerretKoehler Publisher.

Kirkpatrick, L. Donald L dan Kirkpatrick, D .James. (2005). Evaluating Training Programs: The Four Levels. San Francisco: Barret-Koehler Publisher.

Koswara, E. (1989). Motivasi Teori dan Penelitian. Bandung: Angkasa.

Mangkunegara, A. A. (2007). Evaluasi Kinerja SDM. Bandung: PT. Refika Aditama.

Mardjoeki. (2003). Studi Evaluasi Efektivitas Pelaksanaan Pendidikan dan Pelatihan Kepemimpinan Tingkat di Departemen Kehakiman dan HAM Republik Indonesia. Universitas Indonesia Jakarta.

Miles B. Matthew dan Huberman A. Michael. (2009). Analisis Data Kualitatif: Buku Sumber tentang Metode-Metode Baru, Terjemahan Tjetjep Rohendi Rohidi. Jakarta: Penerbit Universitas Indonesia.

Moeheriono. (2007). Pengukuran Kinerja Berbasis Kompetensi. Bogor: PT. Refika Aditama.

Mulyono. (2009). Penelitian Eveluasi Kebijakan, (Online), (http:// mulyono. staff.uns.ac.id/2009/ 05/13/penelitian-evaluasi-kebijakan/, diakses 11 April 2011).

Nasucha, Chaizi. (2004). Reformasi Administrasi Publik. Jakarta: Grasindo.

Noe, Hollenbeck, Gerhart, Wright. (2003). Human Resource Management, Internatioan Edition. New York: The Graw-hill Companies, Inc.

Ombudsman Republik Indonesia. (2016). Ringkasan Eksekutif Hasil Penilaian Kepatutan terhadap Standar Pelayanan dan Kompetensi Penyelengara Pelayanan sesuai Undang-Undang Nomor 25 Tahun 2009 tentang Pelayanan Publik. 
Pedoman Diklat Kepemimpinan Tingkat III Provinsi Sumatera Selatan Tahun 2017.

Peraturan Kepala Lembaga Administrasi Negara Nomor 19 Tahun 2015 tentang Pedoman Penyelenggaraan Pendidikan dan Pelatihan Kepemimpinan Tingkat III.

Peraturan Pemerintah Nomor 101 Tahun 2000 tentang Pendidikan dan Pelatihan Jabatan Pegawai Negeri Sipil.

Philips, Jack L., Ron D. Stone, Patricia Pulliam Philips. (2001). The Human Resources Scorecard: Measuring the Return On Investment, Butterworth-Heinemann: Burlington.

Rangkuti, Freddi. (2003). Measuring Customer Satisfaction. Jakarta: PT. Gramedia Pustaka Utama.

Reksohadiprodjo, Sukanto dan Hani T. Handoko. (2001). Organisasi Perusahaan: Teori Struktur dan Perilaku. Yogyakarta: BPFE-Yogyakarta.

Rika Dwi Kurniasih. (2009). Teknik Evaluasi Perencanaan, (Online), (http:// images. rikania09. multiply. multiplycontent.com/attachment/0/SUdfiwoKCF8AADuyo-81/Rika\%20Eva.doc?nmid=148657139, diakses 12 April 2011).

Rivai, Veithzal. (2004). Manajemen Sumber Daya Manusia untuk Perusahaan : Dari Teori ke Praktik. Jakarta : Raja Grafindo Persada.

Rivai, Veithzal, et.al. (2011). Performance Appraisal. Sistem yang Tepat untuk Menilai Kinerja Karyawan dan Meningkatkan Daya Saing Perusahaan. Jakarta: Raja Grafindo Persada.

Rivai, Veithzal dan Murni, Sylviana. (2009). Educational Management (Analisis Teori dan Praktik). PT. Rajagrafindo Persada: Jakarta.

Robbins, Stephen P. (2001). Managing Human resources, International Edition. New Jersey: Prentice Hall, Inc.

Salusu, J. (1996). PengambilanKeputusan Stratejik: untuk Organisasi Publik dan Organisasi Nonprofit. Jakarta: Grasindo.

Scriven, Michael. (1991). Evaluation Thesaurus, 4th edition. Newbury Park, California: Sage Sage Publications, Inc.

Sedarmayanti. (2009). Manajemen Sumber Daya Manusia, Reformasi Birokrasi dan Manajemen Pegawai Negeri Sipil. Bandung: PT. Refika Aditama.

Simanjuntak J. Payaman. (2005). Manajemen dan Evaluasi Kinerja. Jakarta: Lembaga Perbit Fakultas Ekonomi Universitas Indonesia.

Spaulding, T Dean. (2008). Program Evaluation in Practice: Core Concepts for decision and Analysis. San Fransisco: Wiley Imprint.

Sugiyono. (2005). Metode Penelitian. Bandung: Alfabeta.

Sugiyono. (2009). Metode Penelitian Pendidikan. Bandung: Alfabeta.

Supriyanto. (2007). Pendidikan Orang Dewasa. Jakarta: PT. Bumi Aksara.

Tayipnapis, Farida Yusuf. (1989). Evaluasi Program. Jakarta: Departemen Pendidikan dan Kebudayaan Direktorat Jenderal Pendidikan Tinggi Proyek Pengembangan Lembaga Pendidikan Tenaga Kependidikan.

Tayibnapis, Farida Yusuf. (2010). Evaluasi Program. Jakarta: Rineka Cipta.

Tirtarahardja, Umar dan La Sulo. (1984). Pengantar Pendidikan, Proyek Pembinaan dan Peningkatan Mutu Tenaga Kependidikan Ditjen Pendidikan Tinggi. Jakarta: Departemen Pendidikan dan Kebudayaan.

Undang-Undang Nomor 20 Tahun 2003 tentang Sistem Pendidikan Nasional.

Wibowo. (2010). Manajemen Kinerja. Jakarta: PT. Raja Grafindo Persada.

Widoyoko S, Eko Putro. (2009). Evaluasi Program Pembelajaran: Panduan Praktis Bagi Pendidik dan Calon Pendidik. Yogyakarta: Pustaka Pelajar.

Widoyoko S, Eko Putro. Evaluasi Program Pelatihan, 'Google.com; www.umpwr.ac.id (diakses tanggal 4 Agustus 2017).

Yukl, Gary. (1994). Kepemimpinan dalam Organisasi, edisi Bahasa Indonesia. Jakarta: Prenhallindo.

Yukl, Gary. (2010). Leadership in Organizations, Seventh Edition. New Jersey: Prentice Hall.

Zurnali, Cut. (2004). Pengaruh pelatihan Motivasi terhadap Perilaku Produkvitif karyawan pada Divisi Long Distance PT. Telkom Indonesia, Tbk. Tesis, Program Pascasarjana universitas Padjajaran, Bandung. 